\title{
KURUTULMUŞ ET ÜRÜNLERİNİN KALİTE ÖZELLİKLERİ
}

\author{
Elif Aykın Dinçer*, Mustafa Erbaş \\ Akdeniz Üniversitesi Mühendislik Fakültesi Gıda Mühendisliği Bölümü, Antalya, Türkiye
}

Geliş / Received: 21.12.2018; Kabul / Accepted: 07.05.2019; Online bask1 / Published online: 15.05.2019

Aykın Dinçer, E., Erbaş, M. (2019). Kurutulmuş et ürünlerinin kalite özellikleri. GIDA (2019) 44 (3): 472-482 doi: 10.15237/gida.GD18124

Ayken Dincer, E., Erbas, M. (2019). Quality properties of dried meat products. GIDA (2019) 44 (3): $472-482$ doi: 10.15237/gida.GD18124

\section{ÖZ}

Kurutma, eș zamanlı olarak 1sı ve kütle transferi ile gıdadan suyun uzaklaştırılmasına dayanan kompleks bir işlemdir. Kurutulmuş et ürünleri; sığır, domuz, kümes hayvanları ve balık gibi farklı et kaynağı, baharat, antioksidan ve stabilizatörler gibi fonksiyonel katkı maddeleri ve kürleme, tütsüleme ve kurutma gibi üretim yöntemlerinin kullanılmasıyla çeşitli şekillerde üretilir. Bu yöntemlerle elde edilen kurutulmuş et ürünlerine pastırma, ham, jerky, pemmican, biltong, kaddid ve cecina örnek verilebilir. Ancak, kurutma işlemi sıcaklık ve süre gibi çeşitli faktörler yönünden optimum koşullarda yapılmadığında, et ürünlerinde esmerleşme reaksiyonları, renk kaybı, lipit oksidasyonu, yoğun ve sert bir yap1, boyut küçülmesi, rehidrasyon yeteneğinin azalması gibi birtakım olumsuz değişiklikler meydana gelebilir. Ayrıca, depolama koşulları da kurutulmuş et ürünlerinin kalitesi üzerinde önemli bir etkiye sahiptir. Bu makalede kurutulmuş et ürünlerinin kalite özellikleri ve depolama işleminin ürün kalitesi üzerine etkileri derlenmiştir.

Anahtar kelimeler: Depolama, kalite, kurutma, kurutulmuş et ürünleri

\section{QUALITY PROPERTIES OF DRIED MEAT PRODUCTS}

\begin{abstract}
Drying is a complex process based on simultaneous removal of water from food by heat and mass transfer. Dried meat products are produced in various ways by using different meat sources such as cattle, pig, poultry and fish; functional additives such as spices, antioxidants and stabilizers; and production methods such as curing, smoking and drying. Pastırma, ham, jerky, pemmican, biltong, kaddid and cecina can be exemplified dried meat products obtained by these methods. However, some negative changes such as browning reactions, discoloration, lipid oxidation, intense and hard structure, reduction in dimension and lower rehydration ability may occur in meat products when drying process isn't carried out under optimum conditions for factors, such as temperature and time. Furthermore, storage conditions also have a significant impact on quality of dried meat products. In this article, quality characteristics of dried meat products and effects of storage process on product quality have been compiled.
\end{abstract}

Keywords: Storage, quality, drying, dried meat products

\footnotetext{
${ }^{*}$ Yazışmalardan sorumlu yazar / Corresponding author;

$\bowtie$ elifaykin@akdeniz.edu.tr, $\quad$ (c) (+90) 2423104345
} 


\section{GİRİ̧̧}

Toplum sağllğı için tüketimi oldukça önemli olan kırmızı et, sahip olduğu yüksek su içeriği, su aktivitesi değeri $\left(a_{w} \approx 0.99\right)$ ve zengin besin maddeleri nedeniyle mikrobiyolojik olarak hizlı bir şekilde bozulma riski taşır (Başlar vd., 2014; 2015; Aykın-Dinçer ve Erbaş, 2018). Et ağırllı̆ının yaklaşı \%75 kadarını oluşturan suyun büyük çoğunluğu miyofibrillerin içerisinde bulunurken, daha az bir kısmı ise miyofibriller arasinda bulunur (Traffano-Schiffo vd., 2014). Ette suyun çoğunluğunun miyofibriller içerisinde bulunması etten suyun uzaklaştırılmasını zorlaştırır ve uzun zaman gerektirir. $\mathrm{Bu}$ uzun zamanda ise et mikrobiyolojik olarak bozulabilir. Diğer taraftan etin yapisinda bulunan suyun miktarı ve fizikokimyasal durumu olumsuz biyokimyasal reaksiyonları da artırabilir. Bunlara bağlı olarak da etin kalitesi düşebilir ve raf ömrü kısalabilir.

Genel olarak kurutma, herhangi bir üründeki; mikrobiyolojik, biyokimyasal ve kimyasal faaliyetleri kontrol altına almak için hijyenik şartlar altında ürünün bünyesinde bulunan suyun uygun sicaklık ve/veya nispi nem farklillğ1 prensibi ile üründen uzaklaştırılması ve ürünün su aktivitesi değerinin düşürülmesi olarak tanımlanır (Petit vd., 2014; Kilic, 2017a; b; Ponwiboon ve Rojanakorn, 2017). Etin bozulma riski nedeniyle kurutma işlemi tek başına uygulanmayıp; genellikle tuzlama, kürleme veya tütsüleme gibi işlemlerle birlikte uygulanır (Ahmat vd., 2015). Kurutma işlemi ile ürünün bozulması önlenerek raf ömrü artır1labilir ve ambalajlama, nakliye ve depolama giderleri azalt1labilir (Traffano-Schiffo vd., 2014; Kumar vd., 2017). Kuru et ürünleri bu avantajları sayesinde sporcular, seyahat edenler ve ordu mensupları tarafindan tercih edilir ve ayrica yurt içinde ve dışında güçlü bir şekilde rekabet edebilme şansı da yakalayabilir.

\section{KURUTULMUŞ ET ÜRÜNLERI}

Geçmişten günümüze kadar insanlar, gıdaların uzun süre bozulmadan saklanmasını sağlayacak muhafaza yöntemlerini araştırmış ve yeni muhafaza yöntemleri geliştirmeye çalışı̧ıtır. Hayvansal gidalar arasinda önemli bir yere sahip olan et için de çeşitli muhafaza teknikleri kullanılmış ve geliştirilmiştir. Etlerin tuzlandıktan sonra güneşte kurutulması bilinen en eski muhafaza yöntemlerinden biridir. Geleneksel yöntemde etler güneşte ya da sicaklik uygulamalariyla kurutulur (Martins vd., 2015). Bu yöntemle elde edilen et ürünleri soğuk zincire gereksinim duyulmadan satışa sunulur ve böylece üretim maliyetleri de düşer. Geleneksel yöntemlerle elde edilen bu et ürünleri oda sıcakliğında birkaç hafta ile birkaç ay arasında bozulmadan muhafaza edilebilir (Heldman ve Lund, 2006).

Orta Doğu ve Güney Asya ülkeleri başta olmak üzere birçok ülkede geleneksel olarak üretilen kurutulmuş et ürünleri (Çizelge 1) temel olarak üç gruba ayrilir. Bunlar;

-Tuzlama ve kurutma işlemi ile üretilen ürünler,

-Tuz ve çeşitli katkı maddeleri ile muamele edildikten sonra kurutma ile üretilen ürünler,

-Tuzlama ve kürleme işlemine ilaveten isıl işlem uygulanarak üretilen ürünlerdir.

Çizelge1. Dünya'daki bazı kurutulmuş et ürünleri ve orjinleri (Aykın-Dinçer, 2018)

\begin{tabular}{ll}
\hline Et ürünü & Orjin \\
\hline Charque & Latin Amerika \\
Jerky & Kuzey Amerika \\
Pemmican & Kuzey Amerika \\
Carne-de-sol & Brezilya \\
Biltong & GüneyAfrika \\
Kaddid & Kuzey Afrika \\
Jirge & Afrika \\
Tasajo & Küba \\
Kilishi & Nijerya \\
Qwanta & Etiyopya \\
Cecina & İspanya, Meksika \\
Bündnerfleisch & İsviçre \\
Serano ham & İspanya \\
Black Forest ham & Almanya \\
Parma ham & İtalya \\
Pancetta & İtalya \\
Parma coppa & İtalya \\
Rougan & Çin \\
Roupu & Çin \\
Pastırma & Orta Asya, Türkiye \\
\hline &
\end{tabular}


Pastırma; kendine özgü üretim teknolojisiyle asırlardan beri üretilen Türklere özgü kurutulmuş bir et ürünü olup, temel itibariyle sığır karkaslarının belirli bölgelerinden çıarılan bütün kasların kürlenmesi, kurutulması, kurutmanın belirli aşamalarında baskılanması ve daha sonra da çemen adı verilen bir sos ile kaplanıp tekrar kurutulmas1 ile elde edilir (Aksu ve Kaya, 2005; Akköse ve Aktaş, 2014; Akköse vd., 2018). Pastırmanin anavatanı Orta Asya olup, burada yaşayan Türkler tarafindan uzun yolculuklarda tüketildiği bilinir. Ayrıca, pastırmanın Selçuklular zamanında Anadolu'ya getirildiği ve Osmanlılar zamanında da hüküm sürülen ülkelere yayıldığı ileri sürülür. Ülkemizde pastırma üretimi ikliminin uygunluğu nedeniyle Kayseri başta olmak üzere; Afyon, Ankara, Bursa, Çorum, Çankırı, Erzurum, Erzincan, Karaman, Kastamonu, Sakarya, Sivas ve Tokat illerinde yapilir.

Genellikle kürlenmiş et ürünleri olgunlaştırılmıs, kurutulmuş ve/veya tütsülenmiş bütün et parçalarından oluşur. $\mathrm{Bu}$ et ürünlerinin işleme teknolojileri kuruma yoğunluğuna, olgunlaşma süresine ya da tütsülemeye bağlı olarak farklilık gösterir (Toldrá, 2011). Akdeniz'de yaygın olarak domuz etinden üretilen ve ham olarak adlandirılan kuru-kürlenmiş ürünler tüketilmekte olup, bunlardan İspanya'daki Iberian ve Serranoham, İtalya'daki Parma ve San Danielleham ve Fransa'daki Bayonneham en çok bilinenleridir. Bu kuru kürlenmiş et ürünlerinin ortak özellikleri en az 6 ay olan uzun işlem süresi ve kurumadan sonra \%32-34 ağırlık kaybına sahip olmalarıdır. Çin'de ise Xuanwei, ChingHua ve Yunnanbam yaygin olarak tüketilen kuru kürlenmiş et ürünleridir. Kuzey Avrupa ve ABD'de üretilen ürünler ise, nispeten diğer kuru kürlenmiş et ürünlerine göre birkaç hafta gibi daha kısa süren bir olgunlaştırma periyoduna sahiptir. Bu ürünlere ABD'de Kentucky ve Virginiaham, Almanya'da Westphalianham ve Finlandiya'da Saunaham örnek verilebilir (AykınDinçer, 2018).

Kuzey Amerika'da üretilen jerky isimli kurutulmuş et ürünü düşük su içeriği, uzun süre depolanabilmesi, küçük boyutlarda olması ve kolay taşınabilmesi gibi özellikleriyle atıstırmalık gıdaların önemli bir parçasıdır (Li vd., 2014; Choi vd., 2015). İnce bir şekilde dilimlenmiş bütün kasların tuzlandiktan sonra $50-70^{\circ} \mathrm{C}$ sicaklıklarda kurutulmasiyla elde edilen bu kuru et ürününün üretimi, su aktivitesinin düşürülmesi yoluyla mikrobiyel gelişimin engellenmesi prensibine dayanır (Kucerova vd., 2015). Bu kuru et ürününde, protein içeriğinin $\% 75$ 'i kadar su bulunur. Jerky tipi ürünler; sığır, domuz, kümes hayvanları, geyik ve balık gibi farklı et kaynağı, baharat, antioksidan ve stabilizatörler gibi fonksiyonel katk1 maddeleri ve kürleme, tütsüleme ve kurutma gibi üretim yöntemlerinin kullanılmasıyla çeşitli şekillerde üretilir (Konieczny vd., 2007; Ojha vd., 2017).

\section{KURUTMA İŞLEMİNIN ÜRÜN KALITTESİ ÜZERİNE ETKİSİ} Esmerleşme reaksiyonu ve renk kaybı

Gıdaların rengi üzerine enzimatik ve enzimatik olmayan esmerleşme reaksiyonları önemli etkilerde bulunur. Kurutulmuş et ürünlerinin rengi üzerine ise, kasta bulunan az miktardaki glukoz ve serbest aminoasitlerin kuruma süresi boyunca reaksiyona girmesiyle oluşan ve enzimatik olmayan esmerleşme reaksiyonu olarak tanımlanan Maillard reaksiyonu etkili olur. Maillard reaksiyonu ürünleri, kuru etin rengi yanı sıra tekstürü, aroması, lezzeti ve besin değeri üzerine de etkili olur. Bunlara ilaveten, kurutulmuş et ürünlerinde et rengi, tüm kesilmiş dilim boyunca homojen olmalıdır (Heldman ve Lund, 2006).

Nathakaranakule vd. (2007), tüketime hazır makarnalarda ingredient olarak kullanılacak tavuk etini farklı şekillerde kombine edilmiş kızgın buharlı bir kurutucuda kurutmuşlardır. Kurutulmuş ürünlerin parlaklığı azalırken, kırmızılığ1 kurutma sıcaklığına bağlı olarak artmıştır. Ürünün rengindeki bu değişikliklerin yüksek kurutma sicaklığında meydana gelen esmerleşme reaksiyonları sonucunda oluştuğu bildirilmiştir. Yapılan başka bir çalışmada havada kurutma sırasında diğer kalamar çeşitlerine göre Japon kalamarlarının (Todarodespacificus) yüksek proteaz aktivitesi ve arginin ve riboz konsantrasyonuna bağlı olarak daha fazla kahverengileştiği saptanmıstır. Ayrıca, kurutulmuş çiğ etin haşlandıktan sonra kurutulmuş örneklere 
göre daha fazla kahverengileştiği tespit edilmiştir (Geng vd., 2015).

Kurutulmuş kırmızı et ürünlerinde renk gelissimi etteki miyoglobinin formu ve miktarı ile ilişkilidir (Toldrá, 2011). Sığır ve domuz etlerinin rengi üzerine düşük sıcaklıkta vakum ve dondurarak kurutma yöntemlerinin etkisinin araştırıldığı bir çalışmada, sıcaklık artışının ve dondurarak kurutma yönteminin örneklerde daha çok miyoglobin kaybına neden olduğu tespit edilmiştir (King ve Chen, 1998). Yapılan başka bir çalışmada da, taze et örneklerine göre dondurarak kurutulmuş kırmızı et örneklerinin $L^{*}$ ve $b^{*}$ değerlerinin daha yüksek ve $a^{*}$ değerinin ise daha düşük olduğu tespit edilmiş ve bu durumun kurutma sırasında miyoglobin proteininin üç boyutlu yapisinin deformasyonundan kaynaklandığı değerlendirilmiştir (Aykın ve Erbaş, 2016).

\section{Lipid oksidasyonu}

Kurutulmuş gidalarda lipid oksidasyonu ransit tada, kötü lezzet oluşumuna ve yağda çözünen vitaminlerin ve pigmentlerin kaybina neden olur (Heldman ve Lund, 2006). Kuru kürlenmiş et ürünlerinde bulunan gliseritler ve fosfolipitler, lipoliz sonucunda serbest yağ asitlerine dönüşür. Lipolizden sorumlu olan enzimler, kas dokudaki lizozomal asit lipaz ve asit fosfolipazlar iken, adipoz dokuda nötral lipazlardır. Lipoliz sonucunda çoğunlukla palmitik, stearik, oleik ve linoleik asitler meydana gelir (Toldrá, 2011). Oluşan bu serbest yăg asitlerinden doymamış olanlar, oksidasyon reaksiyonlarına daha çok yatkınlık gösterir.

Kuru kürlenmiş et ürünlerinde oksidatif reaksiyonlar; lipoksigenazlar gibi kas oksidatif enzimlerinin ya da $1 s ̧ 1 k$, sıcaklık ve metal iyonları gibi çevresel faktörlerin etkisi ile başlar (Fu vd., 2015). Oksidasyon reaksiyonlar1, peroksit radikalleri ile ilerler ve primer oksidasyon ürünü olan hidroperoksitler oluşur. Peroksit radikalleri çok reaktif olup çok düşük konsantrasyonlarda aromaya da katkıda bulunan alifatik hidrokarbonlar, alkoller, aldehitler ve esterler gibi ikincil oksidasyon ürünlerinin oluşmasını da sağlar (Toldrá, 2011).
Jin vd. (2010), kurutulmuş ve kürlenmiş bir et ürünü olan bacon örneklerinin kas içi yağlarında meydana gelen lipoliz ve lipit oksidasyonunu araştırmışlardır. Araştırma sonucunda toplam serbest yağ asidi miktarının fosfolipitlerden daha yüksek olduğu, lipolitik aktivitenin artan işlem süresi ile azaldığı, asidik lipazların nötral lipazlara göre daha aktif olduğu ve yüksek tuz içeriğinin ise asidik lipazın aktivitesini engellerken lipoksigenazın aktivitesini teşvik ettiği tespit edilmiştir. Ying vd. (2016) ise, kurutulmuş ve kürlenmiş kaz eti örneklerinde meydana gelen lipoliz ve lipit oksidasyonu reaksiyonlarını araştırmışlardır. Araştırmada lipoksigenaz ve tiyobarbitürik asit reaktif bileşikleri (TBARS) değerlerinin kürleme ve marinasyon aşamalarında arttı̆̆1, olgunlaşma aşamasında ise azaldığı ve yüksek miktarda tuzun kullanıldığı örneklerde ise lipoksigenaz aktivitesi ve TBARS değerinin arttığ1 tespit edilmiştir.

\section{Boyut küçülmesi ve rehidrasyon}

Kurutma yöntemi ve koşulları; ürünün boyut küçülmesi, porozite ve yoğunluk özellikleri üzerinde etkili olur. Sicaklık uygulaması ve su kayb1 et proteinlerinin yapisinda büzülmelere, gözenek oluşumuna ve mikro yapıda birtakım değişikliklere yol açar. Gıdaların kurutulması sirasında meydana gelen ve materyaldeki düzensiz su ve sıcaklık değişiminden kaynaklanan düzensiz hacim değişiminin yol açtığ kirılma ve çatlamalar önemli kalite bozulmaları olarak tanımlanır (Heldman ve Lund, 2006). Kalamar filetosunun mikro yapısına kızılötesi ile kurutmanın etkisinin araştırıldığı bir çalışmada; nem kaybı, protein denatürasyonu ve liflerin büzülmesine bağlı olarak daha yoğun ve sert bir kas lifi yapısının meydana geldiği belirlenmiştir (Deng vd., 2014).

Kurutulmuş gıdaların rehidrasyon yetenekleri kurutma işlem koşulları, etin bileşimi, $\mathrm{pH}$ değeri, yoğunluğu ve gözenekliliğine bağlıdır (Heldman ve Lund, 2006). Büzülme gibi hücresel ve yapisal bozulmalar en aza indirildiğinde ürünün rehidrasyonu en yüksek düzeye ulaşabilir. Dondurarak kurutma işlemi ile elde edilen gözenekli yapıdaki ürünler; daha az büzülme, üstün tat sağlama ve daha iyi rehidrasyon özelliklerine sahiptir (Yalçın ve Şeker, 2016). 
Kızgin buharlı bir kurutucuda kurutulmuş tavuk etinin kalitesinin araştırıldığ bir çalışmada, boyut küçülme oranının uygulanan sıcaklı̆̆a bağlı olduğu ve kontrole göre kızgin buharla kurutma yönteminin örneklerde daha az boyut küçülmesine ve daha yüksek rehidrasyona neden olduğu tespit edilmiştir (Nathakaranakule vd., 2007).

\section{Tekstür}

Nem içeriği, bileşim, pH değeri, örnek boyutu ve kurutma yöntemi gibi faktörler kuru et ürününün tekstürel özelliklerine etki eder. Özellikle çiğ etin pH değeri, kuru kürlenmiş et ürünlerinin üretimi sırasında enzim aktivitesini etkiler. Yüksek $\mathrm{pH}$ değerinde bir hammadde kullanıldığında, proteolitik aktivite yükseldiği için kuru kürlenmiş et ürünleri daha yumuşak, soluk, parçalanabilir ve yapışkan bir yapıya sahip olabilir.

Kurutulmuş et ürünlerinin tekstürü kuruma derecesiyle yakından ilisskilidir. Bu nedenle daha yoğun bir kuruma ve buna bağlı nem kaybına sahip ürünler daha sert dokuya sahiptir. Ayrıca, hızlı kurutma işlemi ürün dişında yoğun bir kuruma sağlarken, ürünün iç kısımlarının daha yüksek nem içeriğinde kalmasını sağlar (Toldrá, 2011). Kuru kürlenmiş ham örnekleri üzerinde yapılan bir çalışmada, kritik su içeriği değerinin (\%60) altında su içeren örneklerin sertliğinde önemli bir artış meydana geldiği ve bunun ürünlerin diş bölgesinde oluşan kabuktan kaynaklandığ1 bildirilmiştir (Serra vd., 2005). Diğer taraftan, sertleşmeye katkıda bulunan etkenlerle proteinlerin proteazlarla parçalanmasına katkıda bulunan etkenler arasında bir denge bulunur. Özellikle kuru kürlenmiş et ürünlerinde bulunan endoproteazlar, peptidazlar ve aminopeptidazlar gibi kas proteazlarının aktivitesi, kürleme sirasında ilave edilen tuz miktarı ile kontrol edilir ve böylece aşırı yumuşak bir yapının oluşması engellenebilir. ŻochowskaKujawska (2016), biceps femoris, semimembranosus ve longissimus lumborum gibi farklı geyik kaslarından üretilen kurutulmuş-kürlenmiş et ürünlerinin tekstürel özellikleri üzerine tuz miktarının (\%4, 6 ve 8) ve kas lifi yapısının etkisini belirlemiştir. Bu çalışmada kırmızı kas lifi ve tuz içeriği yüksek örneklerin daha yüksek sertlik, kohezyon, esneklik ve çiğnenebilirlik değerlerine sahip olduğu belirlenmiştir.

Et gibi kuru gıdaların viskoelastik davranışları gerilim ve deformasyon ilişkisine dayalı olarak incelenir. Kuru et ürünlerinin diğer özellikleri gibi viskoelastik özellikleri de sicaklık ve su içeriğine bağlı olarak değişir (Heldman ve Lund, 2006). Yapılan bir et kurutma çalışmasında kurutmanın farklı zamanlarında örnekler alınmış ve örneklerin duyusal olarak en yüksek çiğnenebilirlik özelliğinin, örneğin nem/protein oranının 0.5 olduğu kuruma süresinde sağlandığ1 tespit edilmiştir (Konieczny vd., 2007).

\section{Lezzet ve aroma}

Kurutulmuş et ürünlerinin lezzeti; üründen ürüne değişebilen baharatların kombinasyonu, endojen enzim aktiviteleri, mikrobiyel aktiviteler, otooksidasyon ve koku bileşiklerinin intereaksiyonu gibi faktörlere bağlıdır. Proteoliz ve lipoliz; kurutulmuş et ürünlerinde görülen önemli enzimatik reaksiyonlar olup, bunları oksidasyon takip eder. Tüm bu reaksiyonlar kurutulmuş et ürünlerinde aroma bileşiklerinin oluşumundan sorumlu olur (Toldrá, 2011). Özellikle kuru kürlenmiş et ürünlerinde proteoliz sonucunda meydana gelen serbest aminoasitler kürlenmiş flavor oluşumuna katkı sağlar.

Gıdanın aroma ve lezzetinden sorumlu uçucu bileşiklerin kaynama noktasi, suyun kaynama noktasından daha düşüktür. Bu nedenle kurutma işlemi sırasında bu bileşikler gıdadan uzaklaşabilir. Kurutma işleminin başlangıcında ürün yüzeyde ince bir kabuk oluşturularak bu bileşiklerin kaybı önlenebilir (Heldman ve Lund, 2006).

Kaban (2009) pastırmanin geleneksel üretimi sırasında uçucu bileşenleri belirlemiş ve toplamda 48 uçucu bileşik tespit etmiştir. Araştırmada, ikinci kurutmanın sonlarında aldehit yapısındaki bileşiklerin en yüksek seviyelere ulaştığını ve aromatik hidrokarbonların ise son üründe baskın uçucu bileşikler olduğunu belirlemiştir. Lorenzo (2014) cecina örneklerinin üretimi sırasinda esterler, aldehitler, hidrokarbonlar, alkoller, furanlar ve ketonlardan oluşan 55 kadar uçucu bileşiğin aroma oluşumuna katkıda bulunduğunu 
bildirmiştir. Sha vd. (2017) Kazakistan'a özgü kuru kürlenmiş sığır etinin aroması üzerine birincil temel bileşenler olarak sırasıyla yağ, doymuş yağ asitleri, TBARS, furanlar, çoklu doymamış yağ asitleri, nem ve hidrokarbonların ve ikincil temel bileşenler olarak da esterler, alkoller, ketonlar ve aldehitlerin etkili olduğunu belirlemişlerdir.

Fu vd. (2015), yaptıkları çalışmada gümüş sazan balığ1 filetolarını sıcak hava, mikrodalga ve mikrodalga-vakum yöntemleriyle kurutmuşlardır. Kurutma işlemi balıksı istenmeyen kokunun azalmasını sağlarken okside olmuş yağ kokusunun artmasina neden olmuştur. Mikrodalgada kurutma işleminin topraksı-küfsü kokuyu büyük ölçüde azalttığ1, mikrodalga ve mikrodalga vakum yöntemleriyle kurutulan örneklerin TBARS değerlerinin daha düşük olduğu ve TBARS değerinin mikrodalga kurutma sırasında güç yoğunluğu ile azalırken, vakum işlemiyle arttığ1 belirlenmiştir.

\section{Mikrobiyolojik kalite}

Mikroorganizmaların gelişimi için taze et ideal bir ortam olmasina rağmen; gastrointestinal sistem, solunum yolları ve lenf dügümleri haricinde hayvanın iç kısmında organizmalar bulunmaz. Ancak, kesimden önce ve işleme sırasındaki çevresel koşullar et yüzeyindeki kirlilik derecesini ve etin mikrobiyel bozulmasını etkiler. Diğer taraftan, işlenmiş et ürünlerinde taze ete göre farklı bir mikrobiyel grup bulunur. Özellikle, su aktivitesi aralığ1 $0.60-0.90$ olan ve orta nemli olarak tanımlanan et ürünlerinde bazı bakteriler (Pediococcus, Streptococcus, Micrococcus, Lactobacillus, Vibrio ve Staphylococcus), mayalar (Hansenula, Candida, Hanseniaspora, Torulopsis, Debaryomyces ve Saccharomyces) ve küfler (Cladosporium, Paecilomyces, Penicillium, Aspergillus, Emericella, Eremascus, Wallemia, Eurotium, Chrysosporium ve Monascus) gelişebilir. Bu mikroorganizmaların büyük bir kısmı üründe bozulmaya ve tüketici de sağlık sorununa sebep olabilir (Huang ve Nip, 2001).

Kesimle birlikte ete bulaşan soğuğa dayanıklı Enterobacter spp., Proteus spp., Citrobacter spp. ve özellikle Serratia spp. gibi Enterobacteriaceae familyası üyesi mikroorganizmalar da üründe bozulmaya neden olur. Bunlara ilaveten, bozulmuş ürünlerde Clostridium and Staphylococcus cinsi mikroorganizmalar da bulunabilir. Gidanın su aktivitesi değeri 0.95 in altına düşürüldügünde Clostridium botulinum'un A ve B tipi ile $C$. perfringens'in gelişimi engellenebilirken, aerobik koşullarda 0.86 su aktivitesi değerine kadar Staphylococcus aureus gelişim gösterebilir (Huang ve Nip, 2001).

Gıdanın su aktivitesi 0.85 değerinin altına düşürülmesiyle mikroorganizmaların gelişimi engellenebilir, fakat bu işlem ürünü güvenli hale getirmez. Kurutma işleminin sıcaklığ mikroorganizmaların sayısını azaltırken canlı kalabilen ve gidada bozulma yapabilen mikroorganizmalar üründe sorunlara neden olabilir (Heldman ve Lund, 2006). Kuru kürlenmiş et ürünlerinin mikrobiyel güvenliğini etkileyen başlica patojen Listeria monocytogenes'dir. $\mathrm{Bu}$ mikroorganizma insanlarda listeriosis gibi ciddi enfeksiyonlara neden olabilir. Listeriosis kaynaklı ölümlerin oranı $(\% 20)$ oldukça yüksek olduğundan, ürün pazarlanmadan önce $L$. monocytogenes'in ortadan kaldırilmasi veya azaltılması gerekir (Sara vd., 2014). ABD Tarım Bakanlığ1 Gıda Güvenliği ve Denetimi Birimi (FSIS/USDA) tüketime hazır gidalarda $L$. monocytogenes için sıfır tolerans politikasını uygular. Avrupa Birliği ise, bu ürünler için $100 \mathrm{kob} / \mathrm{g}$ değerinde bir gida güvenliği hedefi belirlemiştir. Kurutulmuş et ürünün mikrobiyel açıdan daha stabil olmasını sağlamak amacıyla; nitrit kullanımı, düşük $\mathrm{pH}$, tuz ilavesi, vakum ambalajlama ve isıl işlem gibi faktörler bir arada uygulanır (Huang ve Nip, 2001). Plavsic vd. (2015) tarafindan ev yapımı kurutulmuş ve tütsülenmiş bir et ürününün özelliklerinin araştırıldığı bir çalışmada, son ürünün $\% 37.8$ su, $\% 5.1$ tuz içerdiği ve su aktivitesi değerinin 0.89 olduğu, maya ve küf sayısının ise sırasıyla $10^{7}$ ve $10^{6} \mathrm{kob} / \mathrm{g}$ olduğu tespit edilmiştir.

Scheinberg vd. (2014), yüksek basınç uygulama ve kaynar suya daldırma olmak üzere iki farklı işlemin jerky üretimi sırasındaki patojen sayısını azaltmaya etkisini araştırmışlar ve yüksek basınç uygulamasinin (550 MPa, 60s) Salmonella spp. sayisinda $6.83 \mathrm{log} \mathrm{kob} /$ şerit ve E. coli O157:H7 sayısında ise $4.45 \log \mathrm{kob} /$ şerit düzeyinde önemli bir azalma sağladığını ancak $L$. monocytogenes 
sayısında $1.28 \log \mathrm{kob} /$ şerit ve $S$. aureus sayısında $1.32 \log \mathrm{kob} / s ̧ e r i t$ olmak üzere daha düşük bir azalma sağladığını tespit etmişlerdir. Kaynar su uygulamasinin $\left(100 \pm 2^{\circ} \mathrm{C}, 20-30\right.$ s) ise; Salmonella spp., E. coli O157:H7, L. monocytogenes ve S. aureus sayıların $5.0 \mathrm{log} \mathrm{kob} /$ şerit düzeyinden daha fazla azalttığını belirlemiştir.

Kurutulmuş et ürünlerinde mikroflora genellikle Koagulaz (-) stafilokoklardan oluşur. $\mathrm{Bu}$ mikroorganizmalar stabil ve güçlü bir et renginin oluşmasına katkı sağlar ve sahip olduğu katalaz enzimi ile hidrojen peroksiti parçalayarak uzun süre kurutulmuş üründeki acılaşmayı geciktirir. Hava ile kurutulmuş et ürünlerinde ise mikroflora genellikle LAB'den oluşur. Son üründe bulunan ve birlikte sayılan Staphylococcus, Micrococcus ve Pediococcus cinslerinin say1s1 $10^{5}-10^{6} \mathrm{kob} / \mathrm{g}$ ürün aralığında değişir. Öz vd. (2017), 14 farklı üreticiden temin edilen pastırma örneklerinden 106 farklı tür LAB'sini izole etmişler ve izolatların \%27.4'ünü Lactobacillus sakei, \%24.5'ini Weissella cibaria ve \%19.8'ini $W$. confusa olarak tanımlamıslardır. Ayrıca, pastırma örneklerinde Micrococcus/Staphylococcus, LAB ve maya-küf say1larının sirasiyla $5.28-7.69,3.30-7.90$ ve 2.30 $6.42 \mathrm{log} \mathrm{kob} / \mathrm{g}$ aralığında olduğu ve Enterobacteriaceae sayısının ise tespit edilebilir düzeyin altında (< $2 \begin{array}{llll}< & \log & \mathrm{kob} / \mathrm{g}) & \text { olduğu }\end{array}$ belirlenmiştir.

\section{DEPOLAMA İŞLEMINININ ÜRÜN KALİTESİ ÜZERİNE ETKİSİ}

Taze ve işlenmiş et ürünlerinde kullanılan ambalajlama teknolojileri temel olarak atmosferik ambalajlama (AP), vakumlu ambalajlama ve modifiye atmosfer ambalajlama (MAP) şeklinde sinıflandirilır (Yu vd., 2018). AP uygulamasinda gıdanın içinde bulunduğu havanın bileşimi \%78 azot $\left(\mathrm{N}_{2}\right)$, \%21 oksijen $\left(\mathrm{O}_{2}\right)$, az miktarda karbondioksit $\left(\mathrm{CO}_{2}\right)$, su buhar1 ve diğer gazlardan oluşur. Vakum ambalajlamada gıdayı çevreleyen hava uzaklaştırllır ve düşük $\mathrm{O}_{2}$ geçirgenliğine sahip bir film kullanılır. Bu yöntemle, gidanın $\mathrm{O}_{2}$ ile temas1 sonucunda meydana gelebilecek bozulmaların önüne geçilebilir. Ancak, vakum ambalajlamanın en önemli dezavantaj1 C. botulinum gibi anaerobik patojenlerin gelişimi ve toksin üretimi için uygun ortam sağlamasıdır. Vakum ambalajlamada görülen bu mikrobiyolojik bozulmaların ve basincin gida maddesi üzerindeki zararlı etkilerinin önüne geçebilmek amaciyla MAP uygulaması geliştirilmiştir.

MAP, gıdanın raf ömrünü ve güvenliğini arttırmak için ambalaj içindeki gaz atmosferinin arzu edilen gaz bileşimine dönüştürülmesi işlemi olup çoğunlukla $\% 75 \mathrm{~N}_{2}$ ve $\% 25 \mathrm{CO}_{2}$ olarak uygulanır. MAP işlemi minimal işlenmiş gıdaların raf ömrünü uzatma özelliğinin yanı sıra yüksek ürün kalitesi ve koruyucu kullanımını azaltma gibi ilave faydalar da sağlar (Wani vd., 2014). MAP işlemi, duyusal ve mikrobiyolojik kaliteyi sağlama amacıyla genellikle soğuk depolama ile birlikte uygulanır. MAP uygulamasinda $\mathrm{CO}_{2}$ gazı $(\geq$ $\% 20$ ), aerobik bakteri gelişiminin lag fazını uzatma ve logaritmik fazda çoğalma hızını azaltma için kullanilır. Ancak, yüksek konsantrasyonlarda $\mathrm{CO}_{2}$ kullanımı lezzet bozulmasi ve ambalajda çökme gibi sorunlara neden olabilir. İnert bir gaz olan $\mathrm{N}_{2}$ ise; oksidasyonu, lezzet bozulmaların ve $\mathrm{CO}_{2}$ 'in neden olduğu çökmeleri önlemek için kullanilır.

Taze meyve ve sebzelerde genellikle anaerobik solunumu ve yoğunlaşmayı önlemek için optimal düzeyde $\mathrm{O}_{2}$ içeren ve belli bir miktar su buharı geçirgenliğine sahip ambalajlamaya ihtiyaç duyulur. Çiğ soğutulmuş etlerde depolama sırasında görülen solunum ise taze meyve sebzelerde olduğu gibi belirgin değildir. Posmortem kas mitokondrisi $\mathrm{O}_{2}{ }^{\prime} \mathrm{i}$ metabolize etmeye devam ederken, posmortem zamanina bağlı olarak aktif $\mathrm{O}_{2}$ tüketimi ve $\mathrm{CO}_{2}$ oluşumu azalır. Dolayısıyla taze etlerin ambalajlanmasinda daha yüksek düzeylerde $\mathrm{O}_{2}$ arzu edilirken, işlenmiş etlerde daha düşük konsantrasyonlarda kullanılabilir. Taze et ürünlerinin ambalajlanmasında yüksek $\quad \mathrm{O}_{2}$ konsantrasyonunun tercih edilmesinin nedeni; kırmızı renkli myoglobin pigmentinin parlak kiraz kırmızısı renkli oksimyoglobine dönüşmesini sağlamaktır. Aksi durumda düşük $\mathrm{O}_{2}$ konsantrasyonu oksimyoglobinin metmyoglobine okside olmasina neden olur. Özellikle taze etler $\% 80 \mathrm{O}_{2}$ ve $\% 20 \mathrm{CO}_{2}$ ve işlenmiş et ürünleri $\% 70$ $\mathrm{N}_{2}$ ve $\% 30 \quad \mathrm{CO}_{2}$ içeren modifiye atmosfer ambalajlarda depolanır. Dolayısıyla, her ürün için 
optimum gaz kompozisyonlarının kullanımı gerekir (Wani vd., 2015).

AP ve vakum ambalajlamaya göre MAP işlemi kurutulmuş et ürünlerinin kimyasal, mikrobiyolojik ve duyusal özelliklerini daha iyi koruyabilir. Aksu ve Kaya (2005), dilimlenmiş pastırmanin MAP (\%50 $\mathrm{N}_{2}$ ve $\left.\% 50 \quad \mathrm{CO}_{2}\right)$ uygulamasıyla 150 gün depolanabileceğini ve $4^{\circ} \mathrm{C}$ 'de depolanan örneklere göre $10^{\circ} \mathrm{C}$ 'de depolanan örneklerin daha yüksek TBARS değerine sahip olduğunu ancak, renk özelliklerini daha iyi koruyabildiğini tespit etmişlerdir. Parra vd. (2010) $4^{\circ} C^{\prime}$ de 120 gün depolanan Iberian ham örneklerinin TBARS değerini en düşük vakum ambalajlanan ve en yüksek $\% 40 \mathrm{CO}_{2}$ uygulanan örneklerde belirlemişlerdir. Parra vd. (2012) tarafindan yapılan başka bir çalışmada ise; $4^{\circ} \mathrm{C}$ 'de 60 gün boyunca karanlıkta depolanan Iberian ham örneklerinin daha açık renge, düşük TBARS değerine ve hekzenal içeriğine sahip olduğu belirlenmiştir.

Piras vd. (2016) 2 ve $8^{\circ} \mathrm{C}$ 'de depolanan vakum ambalajlanmış ham örneklerinin mikrobiyel profilini koagülaz negatif stafilokoklar ve Pseudomonas spp. bakterilerinin oluşturduğunu, depolamanın 63. gününde TAMB sayısının önemli düzeyde bir artış göstererek bozulma sınırı olan 7 log kob/g'a ulaştı̆ını ve ham dilimlerinin kabul edilebilir raf ömrünün 43 gün olduğunu belirlemişlerdir. Olmo vd. (2014) 120 gün depolama süresince Gram-negatif bakterilerin kontrolünü sağlamada vakum ambalajlanmış lacon örneklerine $500 \quad \mathrm{MPa}$ yüksek basınç uygulamasının en iyi korumayı sağladığını belirlemişlerdir. Rubio vd. (2006), $6^{\circ} \mathrm{C}$ 'de 210 gün depolanan cecina örneklerinin $\mathrm{pH}$ değerinin depolama süresince arttı̆̆ını ve su aktivitesi değerinin ise vakum uygulanan örneklerde azalırken, MAP uygulanan örneklerde değişmediğini belirlemişlerdir. Aynı çalışmada, MAP grubu örneklerin mikrobiyel yükleri vakum uygulanan örneklere göre daha düşük tespit edilmiştir. Kim vd. (2014) benzer olarak, MAP uygulanan kuru kürlenmiş örneklerin TAMB say1s1 ve Enterobacteriaceae sayisinı vakum ambalajlanmış örneklere göre daha düşük tespit etmişlerdir. Ayrıca, depolama süresince tüm örneklerde duyusal özelliklerin azaldığını belirlemişlerdir. Zouaghi ve Cantalejo (2016) ise, $\% 40$ 'dan fazla $\mathrm{CO}_{2}$ içeren MAP uygulamalarının örneklerin duyusal sertlik ve çiğnenebilirlik özelliklerini düşürdüğ̈nü ve dondurarak kurutulmuş tavuk etinin ambalajlanması için en uygun MAP koşulunun \%80 $\mathrm{N}_{2}$ ve $\% 20 \mathrm{CO}_{2}$ bileşimi şeklinde olduğunu belirlemişlerdir.

\section{SONUÇ}

En eski muhafaza yöntemlerinden biri olan kurutma, geçmişte sadece güneşte doğal yolla yapilırken günümüzde teknolojinin ilerlemesiyle çok farklı yöntemlerle uygulanmaya başlanmıştır. $\mathrm{Bu}$ yöntemler temel olarak, su aktivitesinin düşürülmesi yoluyla mikrobiyel gelişimin engellenmesi prensibine dayanır. Ancak, kurutma yöntemi ve koşuları her zaman gida güvenliğini sağlayamamakla birlikte ürünün rengi, lezzet ve aromas1, boyutu ve tekstüründe çeşitli sorunlara neden olabilmektedir. Sonuç olarak; bu derlemede optimum kurutma ve depolama koşulları sağlanarak yüksek kalitede kurutulmuş et ürünlerinin üretilmesi gerekliliğine yer verilmiştir.

\section{KAYNAKLAR}

Ahmat, T., Barka, M., Aregba, A.-W., Bruneau, D. (2015). Convective drying kinetics of fresh beef: An experimental and modeling approach. J Food Process Pres, 39: 2581-2595, doi: 10.1111/jfpp. 12508 .

Akköse, A., Aktaş, N. (2014). Curing and diffusion coefficient study in pastırma, a Turkish traditional meat product. Meat Sci, 96: 311-314, doi: 10.1016/j.meatsci.2013.07.026.

Akköse, A., Kaban, G., Karaoğlu, M.M., Kaya, M. (2018). Characteristics of pastırma types produced from water buffalo meat. Kafkas Univ Vet Fak Derg, 24(2): 179-185, doi: 10.9775/kvfd.2017.18551.

Aksu, M.I., Kaya, M. (2005). Effect of storage temperatures and time on shelf-life of sliced and modified atmosphere packaged pastırma, a dried meat product, produced from beef. J Sci Food Agric, 85: 1305-1312, doi: 10.1002/jsfa.2118.

Aykın, E., Erbaş, M. (2016). Quality properties and adsorption behavior of freeze-dried beef 
meat from the Biceps femoris and Semimembranosus muscles. Meat Sci, 121: 272-277, doi:10.1016/j.meatsci.2016.06.030.

Aykın-Dinçer, E. (2018). Kurutulmuş et ürünü üretmek için soğuk kurutucu tasarımı ve elde edilen kuru et ürününün kuruma-kalite karakteristiklerinin belirlenmesi. Akdeniz Üniversitesi Fen Bilimleri Enstitüsü Gida Mühendisliği Anabilim Dalı Doktora Tezi, Antalya, Türkiye, $121 \mathrm{~s}$.

Aykın-Dinçer, E., Erbaş, M. (2018). Drying kinetics, adsorption isotherms and quality characteristics of vacuum-dried beef slices with different salt contents. Meat Sci, 145: 114-120, doi: 10.1016/j.meatsci.2018.06.007.

Başlar, M., Kiliçli, M., Yalinkiliç, B. (2015). Dehydration kinetics of salmon and trout fillets using ultrasonic vacuum drying as a novel technique. Ultrason Sonochem, 27: 495-502, doi: 10.1016/j.ultsonch.2015.06.018.

Başlar, M., Kiliçli, M., Toker, O.S., Sağdiç, O., Arici, M. (2014). Ultrasonic vacuum drying technique as a novel process for shortening the drying period for beef and chicken meats. Innov Food Sci Emerg, 26: 182-190, doi: 10.1016/j.ifset.2014.06.008.

Choi, Y.-S., Ku, S.-K., Park, J.-D., Kim, H.-J., Jang, A., Kim, Y.-B. (2015). Effects of drying condition and binding agent on the quality characteristics of ground dried-pork meat products. Korean J Food Sci Anim Resour, 35(5): 597603, doi: 10.5851/kosfa.2015.35.5.597.

Deng, Y., Wang, Y., Yue, J., Liu, Z., Zheng, Y., Qian, B., Zhong, Y., Zhao, Y. (2014). Thermal behavior, microstructure and protein quality of squid fillets dried by far-infrared assisted heat pump drying. Food Control, 36: 102-110, doi: 10.1016/j.foodcont.2013.08.006.

Fu, X., Lin, Q., Xu, S., Wang, Z. (2015). Effect of drying methods and antioxidants on the flavor and lipid oxidation of silver carp slices. LWT Food Sci Technol, 61: 251-257, doi: 10.1016/j.lwt.2014.10.035.

Geng, J.T., Kaido, T., Kasukawa, M., Zhong, C., Sun, L.C., Okazaki, E., Osako, K. (2015).
Mechanism study of high browning degree of mantle muscle meat from Japanese common squid Todarodes pacificus during air-drying. Food Chem, 176: 158-166, doi: 10.1016/j.foodchem.2014.12.029.

Heldman, D.R., Lund, D.B. (2006). Food Dehydration. In: Handbook of Food Engineering, Okos, M.R. (chief ed.), CRC press, New York, the USA, pp. 601-744.

Huang, T.C., Nip, W.K. (2001). Intermediatemoisture meat and dehydrated meat. In: Meat Science and Applications, Hui, Y.H. (chief ed.), Marcel Dekker Inc., New York, the USA, pp. 403442.

Jin, G., Zhang, J., Yu, X., Zhang, Y., Lei, Y., Wang, J. (2010). Lipolysis and lipid oxidation in bacon during curing and drying-ripening. Food Chem, 123: 465-471, doi: 10.1016/j.foodchem. 2010.05.031.

Kaban, G. (2009). Changes in the composition of volatile compounds and in microbiological and physicochemical parameters during pastirma processing. Meat Sci, 82: 17-23, doi: 10.1016/j.meatsci.2008.11.017.

Kilic, A. (2017a). LTHV (Low Temperature and High Velocity) drying characteristics and mathematical modeling of anchovy (Engraulis encrasicolus). J Food, 42(6): 654-665, doi: 10.15237/gida.GD17043.

Kilic, A. (2017b). Mathematical modeling of low temperature high velocity (LTHV) drying in foods. J Food Process Eng, 40(2): e12378, doi: 10.1111/jfpe.12378.

Kim, I.-S., Jin, S.-K., Yang, M.-R., Ahn, D.U., Park, J.-H., Kang, S.-N. (2014). Effect of packaging method and storage time on physicochemical characteristics of dry-cured pork neck products at $10^{\circ} \mathrm{C}$. Asian-Australas J Anim Sci, 27(11): 1623-1629, doi: 10.5713/ajas.2013.13728.

King, V.A.-E., Chen, J.-F. (1998). Oxidation of controlled low-temperature vacuum dehydrated and freeze-dried beef and pork. Meat $S_{c i}$, 48(1-2): 11-19, doi: 10.1016/S0309-1740(97)00070-3.

Konieczny, P., Stangierski, J., Kijowski, J. (2007). Physical and chemical characteristics and 
acceptability of home style beef jerky. Meat Sci, 76: 253-257, doi: 10.1016/j.meatsci.2006.11.006.

Kucerova, I., Hubackova, A., Rohlik, B.A., Banout, J. (2015). Mathematical modeling of thinlayer solar drying of eland (Taurotragus oryx) jerky. Int J Food Eng, 11 (2): 229-242, doi: 10.1515/ijfe2014-0227.

Kumar, A., Elavarasan, K., Kishore, P., Uchoi, D., Devi, H.M., Ninan, G., Zynudheen, A.A. (2017). Effect of dehydration methods on physico-chemical and sensory qualities of restructured-dehydrated fish product. $J$ Food Process Pres, 41: e13277, doi: 10.1111/jfpp.13277.

Li, M., Wang, H., Zhao, G., Qiao, M., Li, M., Sun, L., Gao, X., Zhang, J. (2014). Determining the drying degree and quality of chicken jerky by LFNMR. J Food Eng, 139: 43-49, doi: 10.1016/j.jfoodeng.2014.04.015.

Lorenzo, J.M. (2014). Changes on physicochemical, textural, lipolysis and volatile compounds during the manufacture of dry-cured foal "cecina". Meat Sci, 96: 256-263, doi: 10.1016/j.meatsci.2013.06.026.

Martins, M.G., Martins, D.E.G., Pena, R.D.S. (2015). Drying kinetics and hygroscopic behavior of pirarucu (Arapaima gigas) fillet with different salt contents. LWT - Food Sci Technol, 62: 144-151, doi: 10.1016/j.lwt.2015.01.010.

Nathakaranakule, A., Kraiwanichkul, W., Soponronnarit, S. (2007). Comparative study of different combined superheated-steam drying techniques for chicken meat. J Food Eng, 80(4): 1023-1030, doi: 10.1016/j.jfoodeng.2006.04.067.

Ojha, K.S., Kerry, J.P., Tiwari, B.K. (2017). Investigating the influence of ultrasound pretreatment on drying kinetics and moisture migration measurement in Lactobacillus sakei cultured and uncultured beef jerky. LWT - Food Sci Technol, 81: 42-49, doi: 10.1016/j.lwt.2017.03.011.

Olmo, A.D., Calzada, J., Nuñez, M. (2014). Effect of high pressure processing and modified atmosphere packaging on the safety and quality of sliced ready-to-eat "lacón”, a cured-cooked pork meat product. Innov Food Sci Emerg, 23: 25-32, doi: 10.1016/j.ifset.2014.03.003.

Öz, E., Kaban, G., Bariş, Ö., Kaya, M. (2017). Isolation and identification of lactic acid bacteria from pastirma. Food Control, 77: 158-162, doi: 10.1016/j.foodcont.2017.02.017.

Parra, V., Viguera, J., Sánchez, J., Peinado, J., Espárrago, F., Gutierrez, J.I., Andrés, A.I. (2012). Effect of exposure to light on physico-chemical quality attributes of sliced dry-cured Iberian ham under different packaging systems. Meat Sci, 90: 236-243, doi: 10.1016/j.meatsci.2011.07.007.

Parra, V., Viguera, J., Sánchez, J., Peinado, J., Espárrago, F., Gutierrez, J.I., Andrés, A.I. (2010). Modified atmosphere packaging and vacuum packaging for long period chilled storage of drycured Iberian ham. Meat Sci, 84: 760-768, doi: 10.1016/j.meatsci.2009.11.013.

Petit, T., Caro, Y., Petit, A.S., Santchurn, S.J., Collignan, A. (2014). Physicochemical and microbiological characteristics of biltong, a traditional salted dried meat of South Africa. Meat Sci, 96: 1313-1317, doi: 10.1016/j.meatsci.2013.11.003.

Piras, F., Fois, F., Casti, D., Mazza, R., Consolati, S.G., Mazzette, R. (2016). Shelf life of sliced drycured ham packaged under vacuum. J Food Process Pres, 40: 1223-1228, doi: 10.1111/jfpp.12706.

Plavsic, D., Okanovic, D., Gubic, J., Njezic, Z. (2015). Microbiological and chemical evaluation of dried smoked meat product. Procedia Food Sci, 5: 239-242, doi: 10.1016/j.profoo.2015.09.061.

Ponwiboon, N., Rojanakorn, T. (2017). Desorption isotherms and drying characteristics of Nile tilapia fish sheet. Int Food Res J, 24(3): 1292-1300.

Rubio, B., Martínez, B., González-Fernández, C., García-Cachán, M. D., Rovira, J., Jaime, I. (2006). Influence of storage period and packaging method on sliced dry cured beef "Cecina de León": Effects on microbiological, physicochemical and sensory quality. Meat Sci, 74: 710-717, doi: 10.1016/j.meatsci.2006.06.002.

Sara, S., Martina, C., Giovanna, F. (2014). High pressure carbon dioxide combined with high 
power ultrasound processing of dry cured ham spiked with Listeria monocytogenes. Food Res Int, 66: 264-273, doi: 10.1016/j.foodres.2014.09.024.

Scheinberg, J.A., Svoboda, A.L., Cutter, C.N. (2014). High-pressure processing and boiling water treatments for reducing Listeria monocytogenes, Escherichia coli O157:H7, Salmonella spp., and Staphylococcus aureus during beef jerky processing. Food Control, 39: 105-110, doi: 10.1016/j.foodcont.2013.11.002.

Serra, X., Ruiz-Ramírez, J., Arnau, J., Gou, P. (2005). Texture parameters of dry-cured ham $\mathrm{m}$. biceps femoris samples dried at different levels as a function of water activity and water content. Meat Sci,69(2): 249-254, doi: 10.1016/j.meatsci.2004.07.004.

Sha, K., Lang, Y.-M., Sun, B.-Z., Su, H.-W., Li, H.-P., Zhang, L., Lei, Y.-H., Li, H.-B., Zhang, Y. (2017). Changes in lipid oxidation, fatty acid profile and volatile compounds of traditional Kazakh dry-cured beef during processing and storage. J Food Process Pres, 41: e13059, doi: 10.1111/jfpp.13059.

Toldrá, F. (2011). Improving the sensory quality of cured and fermented meat products. In: Processed Meats Improving Safety, Nutrition And Quality, Kerry, J.P. (chief ed.), Woodhead, Oxford, pp. 508-520.

Traffano-Schiffo, M.V., Castro-Giraldez, M., Fito, P.J., Balaguer, N. (2014). Thermodynamic model of meat drying by infrarred thermography. J Food Eng, 128: 103-110, doi: 10.1016/j.jfoodeng.2013.12.024.

Wani, A.A., Singh, P., Langowski, H.C. (2014). Food technologies: Packaging. In: Encyclopedia of Food Safety, Motarjemi, Y. (chief ed.), Academic Press, Waltham, pp. 211-218.
Wani, A.A., Singh, P., Pant, A., Langowski, H.C. (2015). Packaging methods for minimally processed foods In: Minimally Processed Foods, Siddiqui M.W. (chief ed.), Springer International Publishing, Switzerland, pp. 35-55.

Yalçin, M.Y., Şeker, M. (2016). Effect of salt and moisture content reduction on physical and microbiological properties of salted, pressed and freeze dried turkey meat. LWT - Food Sci Technol, 68: 153-159, doi: 10.1016/j.lwt.2015.12.032.

Ying, W., Ya-Ting, J., Jin-Xuan, C., Yin-Ji, C., Yang-Ying, S., Xiao-Qun, Z., Dao-Dong, P., Chang-Rong, O., Ning, G. (2016). Study on lipolysis-oxidation and volatile flavour compounds of drycured goose with different curing salt content during production. Food Chem, 190: 33-40, doi: 10.1016/j.foodchem. 2015.05.048.

Yu, H.H., Song, M.W., Kim, T.-K., Choi, Y.-S., Cho, G.Y., Lee, N.-K., Paik, H.-D. (2018). Effect of various packaging methods on small-scale hanwoo (Korean native cattle) during refrigerated storage. Korean J Food Sci Anim Resour, 38(2): 338349, doi: 10.5851/kosfa.2018.38.2.338.

Żochowska-Kujawska, J. (2016). Effects of fibre type and structure of longissimus lumborum $(\mathrm{Ll})$, biceps femoris $(\mathrm{Bf})$ and semimembranosus $(\mathrm{Sm})$ deer muscles salting with different $\mathrm{NaCl}$ addition on proteolysis index and texture of dry-cured meats. Meat Sci, 121: 390-396, doi: 10.1016/ j.meatsci.2016.07.001.

Zouaghi, F., Cantalejo, M.J. (2016). Study of modified atmosphere packaging on the quality of ozonated freeze-dried chicken meat. Meat Sci, 119: 123-131, doi: 10.1016/j.meatsci.2016.04.032. 